\title{
DOPAMINE RECEPTOR IN ANTERIOR BYSSUS RETRACTOR MUSCLE OF MYTILUS EDULIS
}

\author{
Issei TAKAYANAGI, Hajime MURAKAMI*, Yumiko IWAYAMA, \\ Yukiko YOSHIDA and Saori MIKI \\ Department of Chemical Pharmacology, Toho University School of Pharmaceutical Sciences, \\ Miyama. Funabashi. Chiba 274. Japan and *Department of Physiology. \\ Nihon University School of Dentistry at Matsudo, Matsudo. Chiba 271, Japan
}

Accepted November 20, 1980

\begin{abstract}
Effects of dopamine. N-methyl-, ethyl-and propyl-derivatives of dopamine, and alpha- and beta-adrenoceptor stimulants on catch contraction of anterior byssus retractor muscle of Mytilus edulis were tested. The test drugs except the beta-adrenoceptor stimulants relaxed catch contraction. Dopamine was most active and substitution of amino group in dopamine with ethyl and propyl decreased activity considerably. The concentration-action curves of dopamine, its derivatives and norepinephrine shifted in parallel with application of haloperidol but were not influenced by the alpha- and beta-adrenoceptor antagonists. These results suggest that relaxation of catch contraction by catecholamines is mediated through a dopamine receptor. This muscle is considered to be suitable for a study of the dopamine receptor.
\end{abstract}

Dopamine relaxes catch contraction in the anterior byssus retractor muscle of Mytilus edulis and is present in the ganglia of Mytilus $(1,2)$. However, little is known of dopamine receptors in this muscle. We investigated the effects of dopamine and its derivative on catch contraction of this muscle and compared the findings with the effects of alpha- and beta-adrenoceptor stimulants.

\section{MATERIALS AND METHODS}

Sea mussels. Mytilus edulis L., collected from the east side of Tokyo bay were used. Mytilus edulis were stored in aerated artificial sea water $(\mathrm{NaCl} 456 \mathrm{mM}, \mathrm{KCl} 11 \mathrm{mM}$. $\mathrm{CaCl}_{2} 2 \mathrm{H}_{2} \mathrm{O} 11 \mathrm{mM}, \mathrm{MgCl}_{2} 6 \mathrm{H}_{2} \mathrm{O} 48 \mathrm{mM}$ and Tris- $\mathrm{HCl} 25 \mathrm{mM} ; \mathrm{pH} 7.8-8.0$ ) at a temperature of about $10^{\circ} \mathrm{C}$ and used within 7 days after collection. Muscle bundles (about $1 \mathrm{~mm}$ in diameter) dissected from the anterior byssus retractor muscle under a pair of forceps were suspended in $10 \mathrm{ml}$ organ bath filled with artificial sea water bubbled with air and kept at 23 to $25^{\circ} \mathrm{C}$. Responses to drugs were recorded isotonically under a tension of $0.2 \mathrm{~g}$. After a $1 \mathrm{hr}$ immersion, the muscle was exposed to acetylcholine $\left(10^{-4} \mathrm{M}\right)$ for 2 min and washed with artificial sea water. We used the muscle in which the relaxation at 5 min after washout of acetylcholine was less than $25 \%$ of the maximum relaxation which was obtained by application of serotonin $\left(10^{-6} \mathrm{M}\right)$. The test drugs were applied at 5 min after washout of acetylcholine and relaxations following a $10 \mathrm{~min}$ exposure to the test drugs were estimated. In order to estimate the maximum relaxation. serotonin $\left(10^{-6} \mathrm{M}\right)$ was applied after the 
muscle had been exposed to the test drug for $10 \mathrm{~min}$. These relaxations were expressed as a percent of the maximum relaxation by serotonin $\left(10^{-6} \mathrm{M}\right)$ (3). After a $2 \mathrm{~min}$ exposure to acetylcholine $\left(10^{-4} \mathrm{M}\right)$ and washing with artificial sea water, one of antagonists was applied for $5 \mathrm{~min}$ and the test drug was given for $10 \mathrm{~min}$ in the presence of the antagonist in order to assess the antagonism between the test drugs and antagonists. The $\mathrm{pA}_{2}$-values of the antagonist were calculated from parallel shifts of the concentration-action curves of the test drugs (4). Drugs used: Dopamine hydrochloride. $\mathrm{N}$-methyl(epinine). $\mathrm{N}$-ethyl- and $\mathrm{N}$-propyldopamine hydrochlorides, which were synthesized by Takagi et al. (5), apomorphine hydrochloride (Sankyo), norepinephrine bitartrate (Wako), isoprenaline hydrochloride (Sigma), trimetoquinol hydrocholoride (Tanabe), prazosin hydrochloride (Pfizer), propranolol hydrochloride (Sumitomo-Kagaku) and serotonin creatinine sulfate (Wako), all in powder form. All concentrations used were presented as salt forms.

\section{RESULTS}

Preliminary tests in this study suggested the possibility that the variance between the responses to the test drugs in muscle bundles obtained from different groups of Mytilus edulis was larger than that within resposes of muscle bundles from the same group of sea mussels. Therefore, the results in our series of experiments represent data obtained from mussels at the same time of year and from one group of sea mussels.

After exposure to acetylcholine and washing with artificial sea water, the muscle spontaneously relaxed to $23.0 \pm 2.5 \%$ (mean \pm S.E.) (Figs. 1-3). The maximum responses to all the test drugs were significantly smaller than responses to serotonin. At present we had no explanation for these phenomena (Figs. 1 and 2). Dopamine was the most potent relaxant while isoprenaline (up to $3 \times 10^{-4} \mathrm{M}$ ) and trimetoquinol (up to $3 \times 10^{-4} \mathrm{M}$ ). beta-adrenoceptor stimulants were inactive. Apomorphine, a dopamine receptor stimulant was a much less active relaxant than dopamine (Fig. 2). The responses to norepinephrine and dopamine

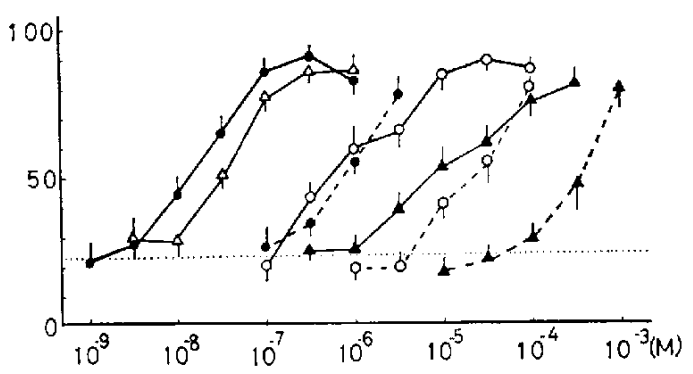

Fig. 1. Resposes to dopamine and its derivatives in the absence and presence of haloperidol. Abscissa: concentration (M); ordinate: percent of the maximum relaxation by serotonin $\left(10^{-6} \mathrm{M}\right)$. Each value is presented as mean with S.E. of 5 to 6 experiments. Solid line: agonist alone: dotted line: agonist with haloperidol $\left(3 \times 10^{-5} \mathrm{M}\right) \mathrm{O}$ : dopamine: $\Delta$ : $\mathrm{N}$-methyldopamine (epinine) $\mathrm{O}$ : $\mathrm{N}$-ethyldopamine: $\mathbf{A}$ : N-propyldopamine. Spontaneous relaxation is presented as a horizontal dotted line.

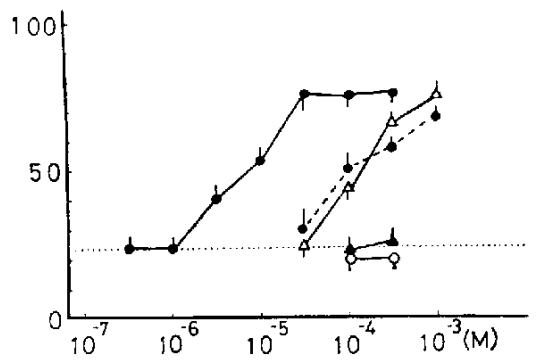

Fig. 2. Responses to norepinephrine, isoprenaline, trimetoquinol and apomorphine in the absence and presence of haloperidol. Abscissa: concentration $(M)$ : ordinate: percent of the maximum relaxation by serotonin $\left(10^{-6} \mathrm{M}\right)$ Each value is presented as mean with S.E. of 5 to 6 experiments. Solid line: agonist alone: dotted line: agonist with haloperidol $\left(3 \times 10^{-5} \mathrm{M}\right)$. norepinephrine: $Q$ : isoprenaline: $\boldsymbol{\Delta}$ : trimetoquinol: $\Delta$ : apomorphine. Spontaneous relaxation is presented as a horizontal dotted line. 

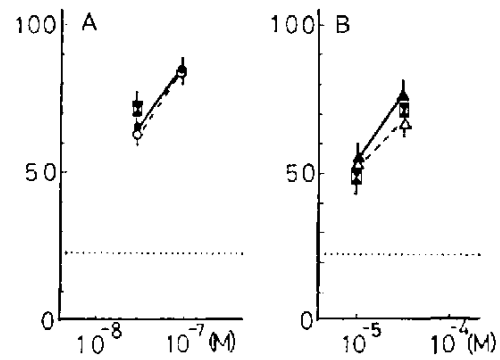

Fig. 3. Responses to dopamine (A) and norepinephrine (B) in the absence and presence of prazosin or propranolol. Abscissa: concentration ( $M$ ): ordinate: percent of the maximum relaxation by serotonin $\left(10^{-6} \mathrm{M}\right)$. Each value is presented as mean with S.E. of 5 to 6 experiments. A) $O$ : dopamine alone; $O$ : dopamine with prazosin $\left(10^{-5} \mathrm{M}\right)$ : $\mathbf{X}$ : dopamine with propranolol $\left(10^{-6} \mathrm{M}\right)$ : B) $\mathbf{A}$ : norepinephrine alone, $\Delta$ : norepinephrine with prazosin $\left(10^{-2}\right.$ $\mathrm{M})$ : $\mathbf{X}$ : norepinephrine with propranolol $\left(10^{-6}\right.$ M). Spontaneous relaxation is presented as a horizontal dotted line.

were not influenced by an alpha-adrenoceptor antagonist, prazosin $\left(10^{-7} \mathrm{M}\right)$ and a beta-adrenoceptor antagonist, propranolol $\left(10^{-6} \mathrm{M}\right)$ in sufficient concentrations to block the responses of the mammalian smooth muscles through the corresponding receptors (Fig. 3). These results suggest that the alpha-and beta-adrenoceptors do not play an important role in relaxing processes of this muscle induced by the test drugs. The concentration-action curves of dopamine, $\mathrm{N}$-ethyl- and $\mathrm{N}$-propyldopamines and norepinephrine were shifted in parallel by a specific dopamine antagonist, haloperidol $\left(3 \times 10^{-5} \mathrm{M}\right)$, thereby suggesting a competitive antagonism (Figs. 1 and 2). The $\mathrm{pA}_{2}$-values of haloperidol were $6.1 \pm 0.21$ against dopamine, $6.0 \pm 0.23$ against $N$ ethyldopamine. $6.2 \pm 0.24$ against norepinephrine. The values are presented as means \pm S.E. of 6 experiments. Substitution of the amino group in dopamine with ethyl and propyl resulted in a considerable reduction in the activity, while $\mathrm{N}$-methyl- dopamine (epinine) was as active as dopamine (Fig. 1).

\section{DISCUSSION}

Dopamine is reportedly released from inhibitory nerves and the catch contraction changes to a response of relaxation $(1,2,6)$. However, little is known of dopamine receptors in the anterior byssus retractor muscle of Mytilus edulis. The betaadrenoceptor stimulants, isoprenaline and trimetoquinol did not relax the catch contraction and relaxation by dopamine and norepinephrine was inhibited by the dopamine antagonist, haloperidol but not by the alphaadrenoceptor antagonist, prazosin and the beta-adrenoceptor antagonist, propranolol. The present results coincide with the findings of others (7), as related to isolated arteries, including renal, mesenteric and femoral, and suggest that relaxation of this muscle by catecholamines is mainly mediated through the dopamine receptors.

The $\mathrm{pA}_{2}$-values of haloperidol to dopamine coincided with a negative logarithm of $K_{i}$ values for haloperidol against the specific binding of ${ }^{3} \mathrm{H}$-dopamine to human caudate. calf caudate and rat striatum (8). Being active in this muscle, apomorphine was much weeker. This result is in agreement with findings on the dopamine receptor in vascular smooth muscle (9). Substitution of the amino group with hydrocarbons larger than methyl yields compounds which have a lesser effect on the dopamine receptors in this muscle. Thus, amine or methylamine would probably be suitable for the cationic head as this head is probably important for the dopamine-receptor interaction (5). Trimetoquinol did not stimulate the dopamine receptors. On the basis of the above results alone, it would appear that the conformation of dopamine required to interact with its receptors is unrelated to the interrelationship between catecholamine and nitrogen in 
trimetoquinol.

Since responses via the alpha- and betaadrenoceptors were not apparent, this muscle is probably suitable for studies on the dopamine receptors.

\section{REFERENCES}

1) Hidaka, T., Yamaguchi, H., Twarog, B.M. and Muneoka, Y.: Neurotransmitter action on the membrane of Mytilus smooth muscle-11. Dopamine. Gen. Pharmacol. 8, 87-91 (1977)

2) Twarog, B.M., Muneoka, $Y$. and Ledgere, M.: Serotonin and dopamine as neurotransmitters in Mytilus: Block of serotonin receptors by an organic mercurial. J. Pharmacol. exp. Ther. 201, 350-356 (1977)

3) Muneoka, Y., Shiba, Y., Maetani, T. and Kanno, Y.: Further study on the effect of mersalyl, an organic mercurial on relaxing response of a molluscan smooth muscle to monoamines. J. Toxicol. Sci. 3, 117-126 (1978)

4) van Rossum. J.M.: Cumulative dose-response curves II. Technique for the making of dose- response curves in isolated organs and the evaluation of drug paremeters. Archs int. Pharmacodyn. Thér. 143, 299-330 (1963)

5) Takagi, K., Takayanagi, I. and Ohta, K.: Actions of dopamine and its derivatives on the taenia caecum and tracheal muscle from the guinea pig and the vas deferens from the rat. Japan. J. Pharmacol. 19, 604-612 (1969)

6) Sweeney, D.: Dopamine: Its occurrenco in molluscan ganglia. Science 139, 1051 (1963)

7) Goldberg, L.I. and Toda, N.: Dopamine induced relaxation of isolated canine renal, mesentric and femoral arteries contracted with prostaglandin $F_{2}$. Circulation Res. 36 and 37 (Supp.). 1-97-1-102 (1975)

8) List, S., Titeler, M. and Seeman, P.: Highaffinity ${ }^{3} \mathrm{H}$-dopamine receptors $\left(D_{3}\right.$ sites $)$ in human and rat brain. Biochem. Pharmacol. 29, 1621-1622 (1980)

9) Goldberg, L.I., Sonneville, P.F. and McNay, J.L.: An investigation of the structural requirements for dopamine-like renal vasodilation: Phenylethylamine and apomorphine. J. Pharmacol. exp. Ther. 163, 188-197 (1968) 